\section{International Scientific Journal Theoretical \& Applied Science}

\section{Oysuluv Jamoliddinovna Urokova}

researcher,

National University of Uzbekistan named after Mirzo Ulugbek gulchehra_3@mail.ru

Year: $2016 \quad$ Issue: 9 Volume: 41

Published: $30.09 .2016 \quad$ http://T-Science.org

SECTION 30. Philosophy.

\title{
CHULPON'S CREATIVE WORK IN THE LEGACY OF THE AESTHETICAL THOUGHT OF MANKIND
}

\begin{abstract}
In this article Chulpon's artistic-aesthetical activity who lived and created at the beginning of the $X X$ century, was a great representative of Uzbek classical literature, jadid enlightener scholar, a translator and a playwright person, appeared in the difficult and complicated period of our history, whose selflessness based on beauty, majesty and creation on the grounds and gained immense prestige in the legacy of aesthetical thought of mankind, is had a conversation. Including, the author of the article shows through Chulpon's creative work that aesthetical culture has been spiritual factor in upbringing of high developed generation in development of a person in the period of jadids and now days. In the article Abdulkhamid Chulpon's creative work has been analyzed in detailed for perfection of this process. So far as today it was interpreted that he had been a real specialist in grace, a lover of beauty, a great master of word. In the article thorough ideas were given that Chulpon - a mighty representative's creative work of the Uzbek literature in the XX century was well known not only in Turkistan lands, even in Russia and a lot of foreign countries and his poetic, artistic works had a serious influence on mankind and Uzbek intelligentsia.
\end{abstract}

Key words: jadidism, enlightenment, Chulpon, aesthetics, nation, spirituality.

Language: English

Citation: Urokova OJ (2016) CHULPON'S CREATIVE WORK IN THE LEGACY OF THE AESTHETICAL THOUGHT OF MANKIND. ISJ Theoretical \& Applied Science, 09 (41): 183-188.

Soi: http://s-o-i.org/1.1/TAS-09-41-32 Doi: crossef http://dx.doi.org/10.15863/TAS.2016.09.41.32

\section{Introduction}

In the period which difficult social life and ca shade of clouds obstructing lights of the sun falling on head of our nation and our country more and more became stronger, Chulpon had not told his own wishhopes in his hearts and dream, his ideal and view openly. He thought to wake up, bring up, put in motion around a drowsy nation wound different social political and economical chains on the basis of which way and ideal, even if his imagination, consciousness and ideal enjoy ideals and lifestyle of our nation matured for long centuries, there was no condition and ability in order to express them openly.

The heart must be a creator as a towel flutters in order to express artistic-aesthetical, philosophical regard like that with respect to life, social system and orders. Chulpon turned his love with respect to life like this, nation and its generation, its nature into strings of the heart and inspiration of creative work. For this reason, his artistic aesthetical feeling, ideas have been sealed up as a pattern of beauty in his each poetic and prose work. After Chulpon has not seen himself wanted and looked for beauty in social life, lifestyle of people, nature and society, he had only and only found beauty, grandiose, fine and wonderful beauty in single dream. Wishes, discontented dreams and aspiration in illusion seemed to be a pattern of beauty, bright ray lighting up the future for him.

Review of literature: Independence developed new regard and approach for spiritual legacy of jadid enlightenment, gave them opportunity of impartial estimation and of reflection withy outlook of period. But it has put issues of investigation of social, educational, historical, moral and aesthetical foundation of jadidism before the philosophers. As a result of this, after independence, view of jadid enlightenment and its representatives have been studied in the philosophical context. Including in the article, the social-philosophical basis of development of jadid motion in the investigation of philosopher scholars such as A.K.Aymatov, G.T.Makhmudova, B.Kasimov, Sh.Rizaev educational-moral view of jadid representatives and the most important of them, place in our national philosophical legacy of them have been analyzed scientifically. 


\section{The methodology}

Steady aims and tasks of reforms carrying out in spiritual sphere in our republic has been made ideological principle as considering the leading scientific conception of the investigation was to regard with national literary legacy reasonably and, impartially and also conceptual approach to problems of perfection in processes of spiritual renovation. This new scientific conception enriches national values of people, its customs and life style with knowledge and vital philosophy which it has stored them itself and gives opportunity to work out all aspects of the problem which is studied on the basis of norm of newly estimation.

The results: thoughts and vies which Chulpon has reserved them for himself about urgent questions of literature and art as a theoretic of the aesthetics, are important for today, too. The results which have been got from the article to improve processes of developing national aesthetic thought expounding philosophical-aesthetic direction of realizing Chulpon's creative work and that it had solid place in the world literary-aesthetic fond, are distinct examples. The social-philosophical essence of artistic-aesthetical symbol in Chulpon's creative work has been analyzed while basing on national and common to all mankind values.

Abdulkhamid Chulpon's creative work appeared in the heavy and difficult period of our history at the beginning of the $\mathrm{XX}$ century, has a special significance.

If we analyze the legacy which the writer has reserved it for himself, we can notice that almost he has taken active more part in all spheres of culture but he has become famous for as a poet. He went under a powerful preventive of Uzbek literature of the XX century for people, his poems had influence on Uzbek intelligentsia seriously. Chulpon's was one of great poets who was able to create and has created a world of peculiar matchless poetry, too.

According to this view it is expedient to interpret Chulpon's creative work in context of a person - a creator - an enlightener in the aesthetics of jaded enlightenment.

Chulpon's creative work is bond up with the theatre directly. It is known that professional company of actors and theatres began to develop in our new Uzbek national theatres in the aesthetic culture of our nation at the beginning of the $\mathrm{XX}$ century. Jadid intelligentsias, who have dreamed triumph of freedom and progress, had turned their attention to the theatre as one of great means in way of upbringing while awaking a nation with light of enlightenment. Chulpon has made a valuable contribution to development of such those theatre companies of actors like other jadids. It is possible to say that only school itself was not sufficient for enlightenment in that period, because it was necessary to inquire about events of time, to want to know condition of motherland, a nation, it is daily life and the same need led Chulpon to the theatre and a press, too. So for as in Bekhbudiy's opinion "the nation needs a mirror that like, may it see its dirty trick and its fascination" [3, p.253].

Chulpon criticizes men who reproaches with people irrelevantly, flaunts its "ignorance" or its "lack of culture" unfoundedly about culture. It is to be observed that spectators often have not gone to some performances at 20s, according to this reason, a talk has spread that people does not go to the theatres. They tried to accuse people of that their cultural standards were low. Chulpon said his final opinion that "the same talk is not right that people does not go to the theatre. People go the theatre. But they have right not to go to puppet show which is called as a performance of the theatre, is strange to its spirit and to "western" woks which they cannot realize them. On the contrary, people go to the performances which attract them and are staged well" [2, p.24] while answering this talk sharply.

Chulpon's patriotism, feeling of national pride and sense of beauty have not prevented from estimating employees of culture, art, literature objectively. When it was necessary he has criticized shortages of culture and policy sharply, too, he has not ashamed to say lacks of lifestyle, its customs and in its heart openly at all. On the contrary, Chulpon does not agree with a doctrine about class character of art. We can know it through his following word "The riches, boybachas (the riches' sons), the children of turas (Mr. from high lineage), khonzodas (generations of khan) who spend his all age for nothing not working, carry along elegance of art in order to be bored from idleness: they play cholgu (an musical instrument), dance, make verses about love and read them. Besides they have five or six theatres like our "coliseum" in big cities. They enjoyed here buying art to money, gold. It is not that the stage does not show foolish life of high layer in the world, on the contrary it shows, but it shows to make spectators smell bitter and nasty smell, strings of cholgu plays some more resent but not crying because the riches danced for their enjoyment if was played with joy in order to make tired people happy in order to remind oppressed people of periods when they were oppressed by crying" [2, p.33].

Chulpon affirmed through his these opinions that art has made vital joys of men and their troubles reflect and sometimes men enjoyed stage works and sometimes cried. As G.Makhmudova said: "The Uzbek professional theatre appeared as fruit of movement of jadidizm glorifying ideas of enlightenment, national independence; gave opportunity people to use a new type of the world culture - stage works. It laid down the foundations to form and develop the national dramatic composition; the main theme in this dramatic composition was to take people out of mire of ignorance thank to 
enlightenment and science, to prepare for new free life. Freedom of Uzbek women, their liberty and human merit were glorified in the stage first time, jadid drama, stage interpretations have developed on the basis of genre, theme, many-colored expression in primary performances yet; performances which had demonstrated fate of nation from daily themes to huge social tragedies, were staged; appearances of actors, producers and composers in the new style and jaded theatre laid down the foundations to develop the Uzbek professional theatre in the future" [4, p.111].

Chulpon looked for possibility of bringing nearer literature to art and he specified that the most acceptable way is truthfulness in order to reach it. The roots of truthfulness are in totality of characteristic peculiar to people. The writer said that it is art and literature which shows life of people in justice. Chulpon discusses about social essence of literature in the article titled "Adabiyot nadur" ("What is literature") published in the newspaper "Sadoi Turkiston" ("Sound of Turkistan") on June, 1914 and gives a) common to all mankind conclusion through an idea called "if a literature lives - a nation does", b) presents a new aesthetic principle of the literature.

In aesthetics of jaded-enlightenment Chulpon's a place of creative work is bond up with thoughts about art of theatre in many aspects. For example he appraised the Meirhold theatre highly and he wants the Uzbek theatre raise in the same level, too. He appraised Mannon Uygur's art highly about this direction; especially he interpreted questions of skill of an actor in aesthetics of theatre. Chulpon says that "paying attention to an actor is attention to a word, if a beautiful word is spoken beautifully. It is not possible that a performance has no influence, the actor who plays excellently and skillfully may he know to speak excellently and skillfully". Summarizing his work on a role in his article titled "Sahna sirlariga oshno sanatkor" ("An artist learned secrets of the stage") devoted to Lutfulla Narzullaev's creative work, he affirms that it is aesthetic requirement, that's, not proper for art but it is general phenomenon: Each creative is remade once and for all, too. A poet's poem, a prose-writer's a novel or a story, composer's musical work, musician's execution; even a jeweler's a smooth ring and a fringe, a petty trader's splendid work .... All of these are made, matured and turns into valuable work with means of remaking" [2, p.39].

It is known that the stage is a sacred place for an actor. At the same time it is necessary not to forget that the spectators pay attention to an actor's outward appearance. According to this reason the producers take notice of this measure especially, too. If actor plays an image given to him skillfully, the spectator forms his aesthetic ideal in figure of that image. Because the spectator calls any of actors not with his own name but he begins to call him with an image which the same actor created. Of course it is actor's great achievement. He was worthy of love of people performing skillfully like that. The actor is one with his name, in spite of everything a role is whether positive or negative if he is charged an image of any of heroes, he acts them with enthusiasm. On the contrary if the actor cannot manage a role charged him, he does not act skillfully, the spectators do not receive him in spite of everything what merit he has. Chulpon interprets these aspects with a number of factors.

First - to change sounds when it is necessary fluent pronunciation of speech is taken into consideration. Because sound of the actor must reach all audience fluently and clearly to the right degree. Well then profession of the actor popularizes peculiar aesthetic culture and reflects it, too.

Second - decoration of the stage must be pictured very skillfully. If what picture a landscape in work has it is required to be shown the same one. If how the actor performances an image charged him, the spectators receive it so, because art of theatre appears before eyes of spectators and there are not a lot of possibilities in it as cinema has.

As is obvious from abovementioned two factors which require skill of art of theatre and profession of an actor, the writer personifies as a specialist of aesthetics in his discourse, articles and reviews informed about theatre of that period.

A.Aytmatov ties Chulpon's views connected with the aesthetics of the theatre and also about development of Uzbek professional theatre, especially skill of profession of an actor together with the writer's article titled "Moskvada ikki turk sanatkori" ("Two Turkish artist in Moscow"). Therefore not confining himself to inform about two Turkish artists living in Moscow, Chulpon approached this event much more widely and deeply. Why have two artists (Er Tugrul Muslimbek and a girl named Munira Ayub, well-known in stage as Nayira Nayir) come to Moscow yet? There are a lot of reasons and meanings under the question. Chulpon ties this case together with a role and significance of artistic condition of Moscow in progress of the world art in that time. Chulpon affirmed that today's Moscow goes in advance than all capitals of the West in many respects of loftiness of art of the theatre. It was clear from the article that Chulpon paid his attention to ideological artistic directions in art of the Russian theatre, too and he says that a new house of art appeared named "Meyrhold theatre" in a number of traditional theatres after the October Revolution. This is really revolution theatre; everything is new, at the same time its news is not permanent "temporary things". For this reason when people speak about this establishment they call it "Istash teatri" ("the theatre of wish"), it is true interpretation, to speak the truth, "Meyrhold theatre" looks for new 
way according to daily demand. Through these thoughts Chulpon estimates achievements in the theatre of the West, that's, in the Meyrhold theatre as a example of theatres endeavoring discovery in art.

Besides abovementioned thoughts specifies Chulpon's view concerning the aesthetics of theatre. Including the theatre in his opinion is a) means of upbringing; b) a factor of developing aesthetic values; c) to direct at enlightenment; d) to arouse love to art; e) to develop cultural level. Chulpon's aesthetic world is wide scale. Translation job is considered important aesthetic section of his activity. Intelligentsias of that period inquired about poet's translations at that time, too. Though it was not very perfection, Chulpon has translated a number of genial works though they were not very perfection. They are "Hamlet" (W.Shakespaer ), "Princess Turandod (K. Gosse)", "The niggard" (Moler), "International" (E.Pote) and also the Uzbek reader at first looked through examples from prose of Russian classical writers such as A.Gogol, S.Turginev, A.Chexov, the novel "A mother" by M.Gorkiy, plays "Do moan", "The truth" by S.Tretyakov, "A man with a suet case" by A.Faykov, "An attack" by V.Yan through Chulpon's translations. Besides Chulpon's aesthetic view some more grew rich in process of translation of works which have important place in literature of people in the world, his literary critical works had essential significance in development of people's aesthetic thought, too.

As the article "Ulug Hindi" ("The great Indian") published in the $7-8^{\text {th }}$ number of journal "Education and teacher" in 1925 seems to devote to insignificant question at first sight, that's, propagating image of the great Indian poet and thinker Rabindranat Tagor and at the same time Chulpon expressed his thought about which way progress of the Uzbek literature had to go on under pretence of Tagor. In the article works of Tagor were interpreted as examples of real art raised to ideal level and on the whole, the Uzbek literature means not only Uzbek writers, all in all it means young people of the East in the new literature who entered the literature at the beginning of the XX century. Chulpon made conclusion that these young people were ill with "lack of way" and he thought that "the old literature was sweet: its new literature is some more sweet: the literature of the West is sweet, too" [2, p.18-19].

While learning Tagor's creative work, Chulpon satisfied his works and he said that Tagor mainly was a golden bridge between the East and the West. Indeed, though Tagor's creative work was born and grew as a whole in India and it had matchless national colors, this creative work is far from national dogmatism. He united both traditions of the East and the West in his creative work. There are conventions, loftiness, wisdom peculiar to the East and also psychologism, operating on the basis of logic of characteristics, argument peculiar to the West in his poetry and novels. In consequence of this he described life of Indian people this way that the description has power which has an influence on the reader in the whole world despite his nationality and a place of inhabitance equally. Common all to mankind problems analyzed with high artistic value granted special profundity and peculiar philosophy to Tagor's works that the same qualities were very attractive for Chulpon.

Abdulkhamid Chulpon began both study of Uzbek Tagor and translation of Rabindranat Tagor's works into Uzbek language. Chulpon who has read Tagor's works with satisfaction and whose heart trembling as list which wind untwined, translated and printed his some poems in the journals "Revolution" and also "Education and teacher" in the $20^{\text {th }}$ of the XX century. As well as the story "Suba" of Rabindranat Tagor was translated and printed by Chulpon in the $9-10^{\text {th }}$ united number of journal "Education and teacher" in 1925. Tagor's majestic photo taken in side and whose bread covered his breast was printed. Chulpon's study of Tagor was seen from date which he marked under his articles written by him, under his poems and stories translated by him and they mainly coincide with 1924-25. An image of the eastern girl, captive oppressed, crying or given in marriage to a man who she did not love by force is available both in Chulpon's prose and his poetry and even in novel titled "Night and light day". It is possible to study the theme of "Suba" and in general Tagor's selections without difficulty by comparing with image of women and girls in Chulpon's creative work especially. It is appropriate to connect reason which the poet began translation of abovementioned story with harmony of themes. It is argument that Chulpon was a founder of school of Uzbek artistic translation. But it is known that the name of Chulpon was not shown as a translator in some works printed in the period of former Soviet government or was announced by others.

An important aspect of Chulpon's creative work is that his artistic works incarnates dramatic characteristics, pictures of sharp dramatic and tragedy roles not only his plays. A clear example of this is hi stories and especially it is possible to say his novel titled "Night and light day".

The novel "Night and light day" by Chulpon was created on the basis of primary stories. When this work was written there was not a big novel except two novels by A.Kodiriy. When Abdulla Kodiriy created "Utgan kunlar" ("The past days"), "Mehrobdan chayon" ("A scorpion from the altar") which were primary examples of genre of Uzbek novel, at first he has learned artistic knowledge from experience of genre of the East novel and works of Jurji Zaydon. Chulpon inquired in contrast to it, not only the East but about school of genre of the West 
novel and he translated a story "Posumiy" ("Sultan of Magoras") by English writer whose name has been unknown to this time in the meanwhile, "Conflict between Ivan Ivanovich and Ivan Nikifrovich" by N.Gogol, a narrative "a story of hung seven men" by L.Andriev, as well as works of representatives of Russian classical literature such as I.Turgenev, A.Chexov, M,Gorkiy into Uzbek language. Acquaintance with literature of the West, that's, a genre of its novel opened new horizons of artistic creative works before Chulpon.

A.Aytmatov studied Chulpon's aesthetic views said, too that the writer was "the golden bridge" between the West and the East: "Chulpon mastered to demonstrate and develop his theoretical and practical principles with respect to artistic creation as a result of deep studying the classical literature of the East and the West, artistic aesthetic legacy of Russian and world writers. He was success to create a peculiar "bridge" uniting aesthetic thought of the East and the West, the world of artistic images with his original works and translations" [1, p.35].

It is known that the aesthetic culture has peculiar place in proving of its high development as structural part of spirituality of a person. Healthy aesthetic culture is closely bound up with high morality, free thought, creative talent and developing aesthetic respect to the world. For this reason, on the one hand, government of our republic has been paying great attention to improving great art of our people. On the other hand, it approaches to protect healthy view, free thought and values in spirit of national and common all to mankind value from spiritual threats and to preserve their original condition, to support them in the form of important political point.

Chulpon's some works were translated by wellknown orientalist, academician A.N.Samoylovich in Russia. Chulpon's works reflected feelings of Uzbek people, its experiences and hopes and he became famous among the Uzbeks in foreign countries. But though these results are how much good, they do not mean that we still realized Chulpon. So realizing Chulpon is not to extol to the skies by praising him or to idealize him but realizing Chulpon is to understand art of word and interior conformity with a law of aesthetics of artistic creation deeply, to understand their reflection in the poet's thought. On the basis of that Chulpon informed that there were jesters such as Tantalone Trufaldino among common people in Italia and traditions which they have created, were very effective and he discussed that images of these jesters were enriched with new qualities and they have moved in Gossy's work. Not satisfying it, Chulpon reflected on interpretations of profession of his producer, Vaxtangov's creative work who died prematurely, staged with excellent skill in his article "Princess Turandot". The most important thing is that Chulpon has taken care of perspectives of Uzbek literature, has looked for ways of joining it a number of advanced literature of the world and he has understood that this way is to adopt leading traditions in the literature of both the West and the East creatively, to conduct leaning on their rich experiences. Chulpon expressed his ideas in his articles at the $20^{\text {th }}$ many times consecutively. For example he spoke about Matyokub and Matyusuf Kharratovs' creative work in the article titled "Ota va bola sanatkorlar" ("A father and a child are artists") and on the way he brought forward questions of learning European music. In this place Chulpon conducted peculiar depth of thought. He refused to learn European music by the way for show and has opened ticklish aspects of the point: Chulpon wrote that "we need knowledge of European music. But knowledge of European music does not consist of a primary theory; it has very importance but difficult stages like harmony. People who entered the first stage of stairs of knowledge of European music if do not climb the following stairs, they can not do things in the musical sphere with this unfinished knowledge" [2, p.20].

As well as realizing Chulpon's aesthetics is to inculcate his great common all to mankind ideas, his high human feelings on heart, to see beauty of nature and majesty of a man through Chulpon's eyes, to feel them with Chulpon's heart.

Thoughts and views which Chulpon has reserved them for himself about urgent questions of literature and art as a theoretic of the aesthetics, are important for today, too. Taking care of formation and development of professional Uzbek theatre, he wrote dramas, translated works of world and Russian classical writers, had an influence on art of the theatre with his articles directly; he brought forward problems such as approaching way of progress, life of people and its traditions, making use of the world culture and preparing for national actors, truthfulness in the stage and natural characteristics in acting.

\section{Conclusion}

Aesthetic consciousness, aesthetic sense, aesthetic dream is reflection of the social life, they have important role in the structure of relations among men, but Chulpon's creative work led to ways to development aesthetic views and artistic thought of people. Following that spiritual foundation, abovementioned thoughts recognizes an influence of movement of Turkistan jadid - enlightenment on renovation of aesthetic view of people and place of Chulpon's creative work. 


\begin{tabular}{l|lrl|l|ll} 
& ISRA (India) & $=\mathbf{1 . 3 4 4}$ & SIS (USA) & $=\mathbf{0 . 9 1 2}$ & ICV (Poland) & $=\mathbf{6 . 6 3 0}$ \\
Impact Factor: & ISI (Dubai, UAE) $=\mathbf{0 . 8 2 9}$ & PUHL (Russia) $=\mathbf{0 . 2 3 4}$ & PIF (India) & $=\mathbf{1 . 9 4 0}$ \\
& GIF (Australia) & $\mathbf{0 . 5 6 4}$ & ESJI (KZ) & $=\mathbf{1 . 0 4 2}$ & IBI (India) & $=\mathbf{4 . 2 6 0}$ \\
& JIF & $\mathbf{1 . 5 0 0}$ & SJIF (Morocco) & $=\mathbf{2 . 0 3 1}$ & & \\
\hline
\end{tabular}

\section{References:}

1. Aymatov A (2011) Chulpon estetikasining goyaviy badiiy asoslari: Synopsis of thesis of dissertation on competition of candidate of philosophical sciences. - Tashkent, 2011. pp.35.

2. (1994) Chulpon. Adabiyot nadur? - Tashkent: Published house named after Chulpon, 1994. pp.39.
3. Kosimov B, Rizaev S (2004) Milliy uygonish davri uzbek adabiyoti. - Tashkent: Manaviyat, 2004. -pp. 253.

4. Makhmudova GT (2006) Jadidizm va Turkistonda axlokiy-estetik fikr tarakkiyoti. Tashkent: "DAVR PRESS", 2006. - pp.111.

5. Rizaev S (1997) Jadid dramasi. - Tashkent: Shark, 1997. 